\title{
Gender Inequality and Intimate Partner Violence Among Women in Moshi, Tanzania
}

\author{
By Laura Ann \\ McCloskey, \\ Corrine Williams \\ and Ulla Larsen
}

Laura Ann McCloskey is associate professor, School of Social Policy and Practice, University of Pennsylvania, Philadelphia, PA, USA.

Corrine Williams is a doctoral student, Department of Society, Human Development and Health, Harvard School of Public

Health, Cambridge, MA, USA. Ulla Larsen is associate professor, Department of Sociology, University of Maryland, College Park, MD, USA.

\begin{abstract}
CONTEXT: In SUb-Saharan Africa, where rates of intimate partner violence are high, knowing the prevalence of abuse and associated patterns of risk is crucial to ensuring women's health and development. Intimate partner violence in Tanzania has not been assessed through a population-based survey.
\end{abstract}

METHODS: A household-based sample of women aged 20-44 in the urban district of Moshi, Tanzania, participated in face-to-face interviews in 2002-2003. The lifetime prevalence of exposure to intimate partner violence and the prevalence of exposure during the past 12 months were assessed among 1,444 women who reported having a current partner. Multivariate logistic regression was used to identify factors associated with intimate partner violence.

RESULTS: Twenty-one percent of women reported having experienced intimate partner violence (i.e., having been threatened with physical abuse, subjected to physical abuse or forced into intercourse by a partner) during the previous 12 months; $26 \%$ reported such an experience at any time, including the past 12 months. The likelihood of violence in the past year was elevated if the woman had had problems conceiving or had borne five or more children (odds ratios, 1.9 and 2.4, respectively); if her husband or partner had other partners (2.0) or contributed little to expenses for her and her children (3.3); and if she had had no more than a primary education (1.7).

CONCLUSIONS: Gender inequality within sexual unions is associated with intimate partner violence. Policies and programs that discourage men from blaming women for infertility, promote monogamous unions and expand access to education for women may reduce intimate partner violence in northern urban Tanzania.

International Family Planning Perspectives, 2005, 31(3):124-130

Violence against women is a global problem, and its prevalence in Sub-Saharan Africa ranks high even in comparison with levels in other developing regions. For instance, as many as $48 \%$ of Zambian married women report ever having experienced intimate partner violence, and $26 \%$ report exposure within the past 12 months; the latter rate is more than twice that obtained through similar surveys in other impoverished regions of the world (e.g., Latin America, Southeast Asia and South Asia). ${ }^{1}$ In Sierra Leone, a staggering proportion (66\%) of women in a convenience sample had ever experienced partner violence. ${ }^{2}$ Population-based household surveys confirm high rates of intimate partner violence among women in rural Uganda (Rakai District)-20\% for the past 12 months and 30\% ever. ${ }^{3}$ Nearly one in 10 South African women report exposure within the past 12 months, and $25 \%$ report lifetime exposure. ${ }^{4}$ Partner violence is so commonplace in some countries in Sub-Saharan Africa that it is accepted as justifiable by more than half of the women themselves, as in Zimbabwe. ${ }^{5}$

Establishing the prevalence of and the associated patterns of risk for intimate partner violence is crucial to addressing women's health and development. Violence places a serious health burden on women and their children, and its role is amplified through its connection to the rising tide of HIV. ${ }^{6}$

To date, no population-based studies have established the rate of intimate partner violence in Tanzania. Few coun- tries hover on as dangerous a health precipice as Tanzania, which ranks among the poorest of African nations and has nearly the lowest life expectancy worldwide (44.6 years). ${ }^{7}$ Almost one in 10 Tanzanians are HIV-positive, and a greater proportion of women than of men in young age cohorts are infected. ${ }^{8}$ The odds of HIV infection among women younger than 30 visiting voluntary testing clinics in Tanzania are 10 times the odds among older women. ${ }^{9}$ It is essential to trace patterns of gender inequality and disease in Tanzania's growing towns and cities.

\section{BACKGROUND}

Characteristics associated with intimate partner violence for women in Sub-Saharan Africa include having less than an eighth-grade education, ${ }^{10}$ having many children ${ }^{11}$ and having experienced sexual abuse during childhood. ${ }^{12}$ South African men who admit to sexually assaulting their intimate partners are more likely than nonabusive men to be physically aggressive outside of marriage, to drink heavily, to express intolerance of their wives' autonomy and to practice polygamy. ${ }^{13}$ However, in East Africa, the dynamics of marriage and fertility are undergoing dramatic change: Women are becoming more autonomous, and family size is decreasing. ${ }^{14}$ One aim of our study was to identify, within a framework of the balance of power within marriage and heterosexual relationships, characteristics of Tanzanian cou- 
ples that are associated with intimate partner violence.

Throughout Sub-Saharan Africa, marriage and sexual unions have long been managed through strong patriarchal traditions and institutions. Tanzania has been no exception, as has been evident in the practices of bride-price, polygamy, paternal control of the choice of marriage partners, emphasis on women's role in fertility and a powerful marriage mandate for women. Yet many of these overt emblems of patriarchy are changing. ${ }^{15}$ Bride-wealth has been supplanted by prospective husbands' payment for women's education fees and health care, ${ }^{16}$ polygamy is declining (although informal extramarital relationships persist); ${ }^{17}$ and women are usually free to choose their husband. ${ }^{18}$ Although women are still expected to marry and to have children, they now exercise somewhat more control over birthspacing and birth control options than they traditionally did. ${ }^{19}$

\section{CONCEPTUAL MODEL}

One approach to understanding the origins of partner violence focuses on the dynamics of men's and women's behavior and the resources that each partner brings to the conjugal union. Such a model draws on theories of social exchange in marriage. ${ }^{20}$ Proponents of social exchange theory contend that implicit or explicit contracts in conjugal relationships are universal, although what is exchanged and how exchanges transpire are culturally governed.

Gender disparities and patriarchal institutions circumscribe the extent of men's license to use violence against their partners. Patriarchy also limits women's agency to abandon an abusive husband. It is important to acknowledge, therefore, that an exchange model to explain domestic violence must be interpreted in light of assumptions about the status of women and the changing dynamics of marriage in Tanzania. We believe that many characteristics associated with intimate partner violence can be conceptualized in terms of gender inequality in sexual unions in Tanzania. In this study, we investigate characteristics of the sexual union and interpret such characteristics within a gender-based framework.

We identified three general domains that reflect underlying power disparities or restrictions of women's options within unions: education (level of schooling completed), features of the union (whether the woman and her partner are legally married, whether he is monogamous and whether he contributes to expenses for her and her children) and fertility (whether the woman has had difficulty conceiving or has had five or more children). Within these three domains, spanning women's life course, gender inequality in Tanzanian marriages or relationships may create the terms for the kind of "sexual contract" that places women at a distinct disadvantage, ${ }^{21}$ setting the stage for intimate partner violence.

As a result of socialist policies, a greater proportion of women receive some education in Tanzania than in many other countries of Sub-Saharan Africa. Nevertheless, educational attainment remains low, and few women reach secondary school. When women are educated, they have oc- cupational alternatives other than being housewives, and possess more choice in their partner or in whether they remain with him. Educated women also expect to be treated in more egalitarian ways than women without education. ${ }^{22}$ We therefore predict that intimate partner violence will be least common among women with the most education.

Most women marry in Tanzania, although separation and widowhood are also common marital "states," and the age at first marriage has been steadily increasing. ${ }^{23}$ It is not always clear from surveys whether formal civil unions have transpired; indeed, in some communities in Sub-Saharan Africa, marriage is a process rather than an event. ${ }^{24}$ But perhaps the most significant conjugal variable is the type of union or marriage, especially whether it is monogamous. ${ }^{25}$ Although polygamy can provide advantages to wives, including an expanded kin network and shared responsibilities, monogamy establishes the foundation for greater potential equality in marriage. Monogamy and free marital choice both contribute to closing the gender gap in power within marriage. ${ }^{26}$ Men who practice polygamy are more inclined than others to view their wives as acquisitions, leaving women with no voice in how resources might be allocated across marriages or households. Women in polygamous unions are likely to have less relationship equality than women in monogamous unions overall. Also, whether men contribute to the family unit is revealing about the nature of their commitment and the likely satisfaction of both marriage partners. Men who contribute more should be more invested and less likely to rely on violence as a tactic of control.

Women's central object of exchange in marriage is a child. A woman who does not bear children early in a marriage is stigmatized in Tanzania, and her appeal as a wife declines. Paradoxically, however, a preference for smaller families is developing in urban areas, including Moshi. Couples who have five or more children are outside of the family-size norms. Women are blamed for either having no children or having too many, and that blame may result in abuse. Furthermore, having many children establishes barriers to economic autonomy and creates the context for pronounced dependency and, ultimately, tolerance of violence. We predict that women who describe problems conceiving or who have had five or more children will report elevated rates of abuse.

\section{METHODS \\ Study Sample}

Moshi Urban District contains 15 wards. Within each ward, clusters were selected with probability proportional to the number of women aged 20-44. In all, 150 clusters were selected for interviewing, and 18 households were selected randomly within each cluster. All women aged 20-44 who were de facto or de jure residents of the selected households were invited to participate in the survey interview. All interviews were in-person and were conducted in Swahili by local nurses after the women provided informed consent. To protect confidentiality, interviewers ensured privacy. The 


\begin{tabular}{|c|c|}
\hline Characteristic & $\begin{array}{l}\% \\
(\mathrm{~N}=1,444)\end{array}$ \\
\hline \multicolumn{2}{|l|}{ CONTROL VARIABLES } \\
\hline $20-24$ & 24.7 \\
\hline $25-29$ & 25.7 \\
\hline $30-34$ & 22.0 \\
\hline $35-39$ & 15.3 \\
\hline $40-44$ & 12.4 \\
\hline \multicolumn{2}{|l|}{ Religion } \\
\hline Muslim & 35.4 \\
\hline Catholic/Protestant/other & 64.6 \\
\hline \multicolumn{2}{|l|}{ Ethnic group } \\
\hline Chagga & 48.1 \\
\hline Pare & 14.5 \\
\hline Other & 37.4 \\
\hline \multicolumn{2}{|l|}{ EDUCATION } \\
\hline \multicolumn{2}{|l|}{ Women's education } \\
\hline scomplete primary & 76.0 \\
\hline$\geq$ some secondary & 24.0 \\
\hline \multicolumn{2}{|l|}{ MARRIAGE } \\
\hline \multicolumn{2}{|l|}{ Marital status } \\
\hline Currently married & 74.6 \\
\hline Currently living with a man & 9.2 \\
\hline Not married or living with a man & 16.2 \\
\hline \multicolumn{2}{|l|}{ Type of union } \\
\hline Monogamous & 72.8 \\
\hline Partner has other wives/girlfriends & 27.2 \\
\hline \multicolumn{2}{|l|}{ Who decided on marriage } \\
\hline Woman and partner & 80.1 \\
\hline Partner/someone else & 19.9 \\
\hline \multicolumn{2}{|l|}{ Partner contributions } \\
\hline Low & 12.7 \\
\hline High & 87.3 \\
\hline \multicolumn{2}{|l|}{ FERTILITY } \\
\hline \multicolumn{2}{|l|}{ Problems conceiving } \\
\hline No & 88.9 \\
\hline Yes & 11.1 \\
\hline \multicolumn{2}{|l|}{ Parity } \\
\hline 0 & 10.8 \\
\hline $1-4$ & 76.2 \\
\hline$\geq 5$ & 13.0 \\
\hline Total & 100.0 \\
\hline
\end{tabular}

interview took 1-2 hours. Participants received no monetary compensation. This research project was approved by the institutional review board of the Harvard School of Public Health; by the Kilimanjaro Christian Medical Centre Research and Ethical Clearance Committee; and by the National Institute for Medical Research, the United Republic of Tanzania.

Between mid-November 2002 and mid-March 2003, a total of 2,019 women completed the interview. Twenty-eight percent of these women reported no current partner and therefore were not asked about partner violence. All but

*The questions from the Conflict Tactics Scale have been modified slightly, as the scale measures respondents' experiences in the past six months. Unfortunately, the many other tactics included in the scale could not be included in the present survey because of time limitations. nine women with a current partner (fewer than 1\%) answered the questions about partner violence. The analyses are based on the 1,444 women for whom complete data on violence history were collected.

\section{Measurement}

-Intimate partner violence. One item from the Conflict Tactics Scale ${ }^{27}$ and two items from the Abuse Assessment Screen ${ }^{28}$ were used to ascertain 12-month and lifetime partner abuse.* The questions administered to Moshi residents were "[In the last 12 months/ever in your life,] how often has your husband or partner (1) insulted or sworn at you? (2) threatened to hurt you physically? (3) hit, slapped, kicked or otherwise physically hurt you?" In addition, women were asked one question from the Sexual Experiences Survey: ${ }^{29}$ "[In the last 12 months/ever in your life,] have you ever had sexual intercourse when you didn't want to because your husband or partner threatened or used some degree of physical force to make you (twisting your arm, holding you down, etc.)?"

Verbal insults were commonly reported, but we excluded them from the measurement of intimate partner violence because we wanted to identify experiences demonstrating the greatest gender inequality and the worst abuse. (Still, verbal insults denote psychological forms of abuse that merit further inquiry in Sub-Saharan African surveys.) Positive responses on the three remaining items (threats of physical abuse, physical abuse and forced sexual intercourse) were counted to indicate the presence of intimate partner violence. We included threats because doing so permits us to cast a somewhat wider net for abuse tactics than does relying exclusively on physical contact, and threats are usually violent in nature (e.g., involving towering over someone with a raised fist). Indeed, threats and physical attacks were highly concordant; $74 \%$ of women reporting threats also reported attacks. Concordance was equally high for sexual assault and physical abuse.

- Demographic characteristics. Survey questions covered a range of demographic control variables: women's age, religion and ethnic group.

- Indicators of relationship inequality. Educational attainment was collapsed into two levels: complete primary school or less (0-8 years), and some secondary school or above (nine or more years). Women were asked their marital status and were classified as currently married, currently liv-

\begin{tabular}{|c|c|c|}
\hline Type of violence & Last 12 months & Lifetime \\
\hline Any & $21.2(18.5-23.9)$ & $26.1(23.0-29.1)$ \\
\hline \multicolumn{3}{|l|}{ Physical } \\
\hline Been threatened physically & $15.1(12.9-17.3)$ & $17.4(15.1-19.8)$ \\
\hline $\begin{array}{l}\text { Been hit, slapped, kicked or } \\
\text { otherwise physically hurt }\end{array}$ & $16.2(13.9-18.5)$ & $19.7(16.9-22.4)$ \\
\hline
\end{tabular}


ing with a man to whom they were not married, or neither married nor living with a man. To assess type of union, interviewers asked all women, regardless of their marital status, whether their partner had other wives or girlfriends. All women who reported that their partner had no other wives or girlfriends were classified as monogamous. We also asked married women who had made the decision for them to marry: they along with their partner, he alone or someone else? To estimate the extent of a man's contributions to the family unit, we asked each woman about her partner's contributions to the household, children's health care, children's school fees and her health care. Men who contributed in two or more categories were classified as making a high level of contribution. Finally, women were asked whether they had had "problems conceiving over a oneyear period," and were asked how many children they had borne.

\section{Statistical Analysis}

The cluster sampling design was taken into account using STATA version $8 .{ }^{30}$ The prevalence of violence was estimated for two time frames: the 12 months preceding the interview and any time during the woman's life (including the last 12 months). The multivariate analysis was restricted to violence in the last 12 months, because some characteristics measured at survey date had changed during the woman's life course (e.g., marital status and type of union). Missing indicator variables were used to maintain the full sample in the multivariate model.

We began by measuring the association between the prevalence of intimate partner violence and each background characteristic using the Pearson chi-square test. Next, we estimated unadjusted relative odds of violence and 95\% confidence intervals, using logistic regression analysis. Then we estimated a multivariate logistic regression model including all of the indicators of relationship inequality and control variables. A correlation matrix including all the independent variables analyzed was also calculated to determine the extent of multicollinearity.

\section{RESULTS}

Three-quarters of the women were younger than 35 (Table 1). Two-thirds were Christian (e.g., Catholic or Protestant), and the remainder were Muslim; 48\% were Chagga, 15\% were Pare and the remaining 37\% belonged to numerous other ethnic groups. Women's educational attainment was generally low; only one-quarter had more than a primary education. A majority of the women were either married or living with a partner, mostly in monogamous unions; $80 \%$ of the married women said that they and their partner had decided jointly to wed. Nearly all reported a high level of partner contributions to expenses for themselves and their children. One in 10 women reported that they had experienced problems getting pregnant. Most had had 1-4 children; $11 \%$ had had none, and $13 \%$ had had five or more.

During the past 12 months, $21 \%$ of women surveyed had been physically or sexually attacked or threatened with vi-
TABLE 3. Percentage of women reporting physical violence in the last 12 months, and odds ratios (and 95\% confidence intervals) from logistic regression analyses examining associations between the likelihood of intimate partner violence and selected characteristics

\begin{tabular}{|c|c|c|}
\hline Characteristic & $\%$ & $\begin{array}{l}\text { Odds ratio } \\
(\mathrm{N}=1,264)\end{array}$ \\
\hline
\end{tabular}

\begin{tabular}{lll}
\hline Total na & 21.2
\end{tabular}

CONTROL VARIABLES

Age

20-24 18.4

$25-29$

$30-34$

35-39

$40-44$

21.4

19.4

23.0

$.06(0.69-1.65)$

$0.78(0.50-1.22)$

$0.71(0.42-1.19)$

Religion

Muslim

$0.70(0.42-1.18)$

Catholic/Prc

1.00

$1.44(0.95-2.19)$

Ethnic group

Chagga

Pare

1.00

Other

$1.03(0.60-1.77)$

$1.25(0.90-1.73)$

\section{EDUCATION}

\section{Women's education}

$\leq$ complete primary

$\geq$ some secondary

$24.2^{* * *}$

11.6

$1.70(1.13-2.58)$

MARRIAGE

Marital status

Currently married

Not married or

living with a man

28.5

21.3

1.00

Type of union

Monogamous

Partner has other

wives/girlfriends

$17.1^{* * *}$

32.1

Who decided on marriage

Woman and partner

Partner/someone else

21.7

25.7

$0.98(0.65-1.46)$

Partner contributions

Low

High

$40.5^{* * *}$

18.5

$3.26(1.99-5.35)$

FERTILITY

Problems conceiving

No

20.3* $\quad 1.00$

$\begin{array}{lll}\text { Yes } & 29.2 & 1.87(1.16-3.01)\end{array}$

Parity

0

$1-4$

$12.5^{* * *}$

$20.1 \quad 1.00$

$\geq 5$

$0.37(0.18-0.74)$

$2.42(1.60-3.66)$

${ }^{*} \mathrm{p}<.05 .{ }^{* * *} \mathrm{p}<.001$. Notes: $\mathrm{p}$ values are from Pearson's chi-square test. na= not applicable.

olence (Table 2): Some 15-16\% reported various types of physical violence, and 1\% a forced sexual experience. Lifetime prevalence of physical and sexual violence was 26\% overall and generally did not differ significantly from prevalence in the past year; the exception was that a higher proportion of women reported ever having been forced to have $\operatorname{sex}(3 \%)$.

The results of the unadjusted and adjusted analyses testing associations between gender and relationship factors and the odds of intimate partner violence yielded parallel 
results; we focus here on findings from the adjusted analyses. (Results of the unadjusted analyses are available from the authors.) Our findings were generally consistent with the conceptual model of relationship inequality and violence.

There were no associations between partner violence in the last 12 months and any of the control variables (Table 3 , page 117). However, education made a difference, such that women with a primary or lower education were more likely than their better educated peers to have been abused (odds ratio, 1.7).

Marital status and freedom to choose a marriage partner were unrelated to intimate partner violence, while polygamous unions were associated with higher odds of violence than monogamous ones (odds ratio, 2.0). Additionally, women whose partners made a low-level financial contribution to the household were more likely to report abuse than were women whose partners made a high-level contribution (3.3).

Fertility variables were associated with violence against women. Women who reported problems conceiving were more likely than those without such problems to experience violence (odds ratio, 1.9). However, women who had had five or more children were the parity group at the highest risk of experiencing partner violence (2.4).

\section{DISCUSSION}

The prevalence of intimate partner violence is high in Moshi, and is similar to the level estimated for rural Uganda. ${ }^{31}$ The finding that lifetime experience with intimate partner violence was not significantly higher than the 12-month rate suggests that the majority of women with an abuse history were still with their violent partner. Our results support our proposed conceptual model of gender inequality in relationships: We have identified several domains in which women are at a disadvantage.

Women with only primary school education or less face an elevated risk of abuse. Women with more education, and hence more career and employment options, may be less likely to be abused because they are perceived as more valuable by their husbands, and perhaps by the extended family; they also may have more power to leave a relationship should their husband become abusive. As women's participation in the domestic economy in East Africa continues to increase, early investments in daughters' education and development could potentially interrupt the cycle of violence in Tanzania. The type of union has major significance for violence. Unions that are either explicitly polygamous or implicitly polygamous because of extramarital relationships on the part of the men are more likely than monogamous ones to be characterized by violence against wives. In addition, men's increased contributions to the household are associated with decreased violence against their wives.

However, whether women are actually married or are cohabiting, or whether the marriage was freely chosen or arranged, has little bearing on whether their partners are violent. These findings might reflect that in present-day Tan- zania, a smaller proportion of marriages are arranged than were in the past. ${ }^{32}$

This cultural shift in marriage patterns can be partly accounted for by increased Westernization, ${ }^{33}$ but it also reflects personal adaptation to scarce economic opportunities. As men leave the community to earn wages, their dominant role in the household wanes, ${ }^{34}$ and during the past two decades, women have been garnering more domestic power in both agriculture and the household economy. ${ }^{35}$ In much of East Africa, women are responsible for maintaining crops and providing family sustenance in the absence of substantial support from their partners. In addition, many Tanzanian women have developed economic ventures of their own and have formed women's economic unions. Under such conditions, women are likely to chafe at men's expression of traditional privileges that use up valuable resources (e.g., taking multiple wives or sexual partners). ${ }^{36}$ Men whose natural hegemony appears challenged might escalate expressions of power, including the use of violence to quell their wives' complaints or requests for support. It is important to examine the subtle dynamics at play between men and women with separate agendas cast against the backdrop of economic strain, political instability and disease. Despite the power of cultural traditions to explain social behavior, what we perceive as culture undergoes dramatic and rapid changes as people confront transnational forces and large changes in the local political economy.

Women's education has also made notable gains. ${ }^{37}$ The gender gap in literacy and educational attainment has been gradually closing since the 1990s, providing women with alternatives to marriage. ${ }^{38}$ As expressed in the words of one young upwardly mobile woman in northern Tanzania, "Why shouldn't education be our husband?"39 Nevertheless, educational attainment has declined across Tanzania, and girls have been disproportionately affected by the reversals in school completion. Such trends would have affected a significant proportion of women in our sample, and should be kept in mind when interpreting the role of education in marriage inequality and violence.

Demographic indicators fail to distinguish abused from nonabused women. The null finding for age is somewhat surprising, given that intimate partner violence worldwide tends to surface when women are younger than 30 . One possible reason the anticipated age pattern fails to emerge is that the younger women benefited from better educational and, ultimately, marriage opportunities than women older than 40; hence the absence of an age trend, with younger women more at risk, might be due to a cohort shift. The information is nevertheless useful for abuse assessment in Tanzania and is contrary to expectations: Older women may be at enhanced risk for violence and should be screened.

\section{Limitations}

This study used data from a population-based survey, and the findings are generalizable to urban women in Tanzania. However, the study has some limitations. First, the data 
were cross-sectional, so the temporal relationship between these characteristics and partner violence cannot be established. Also, all of the women included in the analyses had current partners; the exclusion of women who had left an abusive relationship may affect the results. Another limitation is that the results may not be generalizable to rural populations in Tanzania; for example, having many children may be seen as a burden in an urban area, but it may prove more necessary in a rural area.

\section{Conclusions}

A dire need remains for research into the epidemiology of intimate partner violence throughout many neglected parts of Africa. We still know too little about the cultural underpinnings of violence against women in Sub-Saharan Africa. Such determinants are likely to vary across regions, but a better understanding could inform the development of interventions.

There is little awareness of intimate partner violence as an important health or social issue in Tanzania. Indeed, corporal punishment is legitimated in elementary education, and violence is widely tolerated as a form of social control in both schools and family life. Violence against women is culturally regarded on a continuum with the use of physical punishment to control children, and is broadly accepted. Raising awareness of the damage such violence imposes is important to foster community concern and, ultimately, interventions. Few counselors or social workers are available in the country, much less social workers trained specifically in domestic violence. Further training is desperately needed in such fields. It is especially important to determine whether intimate partner violence heightens the risk for HIV infection, and to design prevention programs that can stem this potential source of suffering and disease propagation. The concentration of HIV in young Tanzanian women further emphasizes the central importance of addressing gender-based violence when proposing policies for public health and economic development.

\section{REFERENCES}

1. Kishor S and Johnson K, Profiling Domestic Violence: A Multi-Country Study, Calverton, MD,USA: ORC Macro, 2004.

2. Coker AL and Richter DL, Violence against women in Sierra Leone: frequency and correlates of intimate partner violence and forced sexual intercourse, African Journal of Reproductive Health, 1998, 2(1):61-72.

3. Koenig MA et al., Domestic violence in rural Uganda: evidence from a community-based study, Bulletin of the World Health Organization, 2003, 81(1):53-60.

4. Jewkes R et al., Prevalence of emotional, physical and sexual abuse of women in three South African provinces, South African Medical Journal, 2001, 91(5):421-428.

5. Hindin MJ, Understanding women's attitudes towards wife beating in Zimbabwe, Bulletin of the World Health Organization, 2003, 81(7):501508 .

6. Dunkle KL et al., Gender-based violence, relationship power and risk of HIV infection in women attending antenatal clinics in South Africa, Lancet, 2004, 363(9419):1415-1421.

7. United States Central Intelligence Agency (CIA), World Factbook, 2003, <http://www.cia.gov/cia/publications/factbook/geos/tz.html\#Econ>, accessed Dec. 11, 2003.
8. Setel PW, A Plague of Paradoxes: AIDS, Culture and Demography in Northern Tanzania, Chicago: University of Chicago Press, 1999; and Kapiga SH et al., The epidemiology of HIV-1 infection in Northern Tanzania: results from a community based study, unpublished manuscript, Harvard University School of Public Health, Boston, MA, USA, 2004.

9. Maman S et al., HIV-positive women report more lifetime partner violence: findings from a voluntary counseling and testing clinic in Dar es Salaam, Tanzania, American Journal of Public Health, 2002, 92(8): 1331-1337.

10. Jewkes R et al., 2001, op. cit. (see reference 4); and Jewkes R, Levin $\mathrm{J}$ and Penn-Kekana L, Risk factors for domestic violence: findings from a South African cross-sectional study, Social Science \& Medicine, 2002, 55(9):1603-1617.

11. Jewkes R et al., 2001, op. cit. (see reference 4).

12. Dunkle KL et al., 2004, op. cit. (see reference 6).

13. Ibid.

14. Abrahams $\mathrm{N}$ et al., Sexual violence against intimate partners in Cape Town: prevalence and risk factors reported by men, Bulletin of the World Health Organization, 2004, 82(5):330-337; Hollos M and Larsen U, From lineage to conjugality: the social context of fertility decisions among the Pare of Northern Tanzania, Social Science \& Medicine, 1997, 45(3):361-372; Bledsoe C, Transformations in Sub-Saharan African marriage and fertility, Annals of the American Academy of Political and Social Science, 1990, 510:115-125; Silberschmidt M, Have men become the weaker sex? changing life situations in Kisii District, Kenya, Journal of Modern African Studies, 1992, 30(2):237-253; Larsen U and Hollos M, Women's empowerment and fertility decline among the Pare of Kilimanjaro region, Northern Tanzania, Social Science \& Medicine, 2003, 57(6):1099-1115; and Stambach A, Schooling, Community and Gender in East Africa: Lessons from Mt. Kilimanjaro, New York: Routledge, 2000.

15. Hollos M and Larsen U, 1997, op. cit. (see reference 14); Bledsoe C, 1990, op. cit. (see reference 14); and Silberschmidt M, 1992, op. cit. (see reference 14).

16. Bledsoe C, 1990, op. cit. (see reference 14).

17. CIA, 2003, op. cit. (see reference 7); and Bledsoe C, 1990, op. cit. (see reference 14).

18. Hollos M and Larsen U, 1997, op. cit. (see reference 14).

19. Ibid.; and Larsen U and Hollos M, 2003, op. cit. (see reference 14).

20. Goode W, Force and violence in the family, Journal of Marriage and the Family, 1971, 33(4):624-636; and Safilios-Rothschild C, A macroand micro-examination of family power and love: an exchange model, Journal of Marriage and the Family, 1976, 38(2):355-362.

21. Pateman C, The Sexual Contract, Stanford, CA, USA: Stanford University Press, 1988.

22. Stambach A, 2000, op. cit. (see reference 14).

23. Larsen U and Hollos M, 2003, op. cit. (see reference 14).

24. Bledsoe C and Pison G, eds., Nuptiality in Sub-Saharan Africa: Contemporary Anthropological and Demographic Perspectives, Oxford, UK: Clarendon, 1997.

25. Hollos M and Larsen U, Which African men promote smaller families and why? marital relations and fertility in a Pare community in northern Tanzania, Social Science \& Medicine, 2004, 58(9):1733-1744.

26. Stambach A, 2000, op. cit. (see reference 14); and Larsen U and Hollos M, 2003, op. cit. (see reference 14).

27. Straus MA, The Conflict Tactics Scale revisited, in: Straus MA and Gelles R, eds., Physical Violence in Families, New Brunswick, NJ, USA: Transaction Publishers, 1990.

28. McFarlane J et al., Assessing for abuse during pregnancy: severity and frequency of injuries and associated entry into prenatal care, Journal of the American Medical Association, 1992, 267(23):3176-3178.

29. Koss MP and Oros CJ, Sexual Experiences Survey: a research instrument investigating sexual aggression and victimization, Journal of Consulting and Clinical Psychology, 1982, 50(3):455-457. 
30. Stata Corp., Stata Statistical Software: Release 8.0, College Station, TX, USA: Stata Corp., 2003

31. Koenig MA et al., 2003, op. cit. (see reference 3).

32. Boerma JT et al., Sociodemographic context of the AIDS epidemic in a rural area in Tanzania with a focus on people's mobility and marriage, Sexually Transmitted Infections, 2002, 78(Suppl. 1):i97-i105.

33. CIA, 2003, op. cit. (see reference 7).

34. Silberschmidt M, 1992, op. cit. (see reference 14).

35. Larsen U and Hollos M, 2003, op. cit. (see reference 14).

36. Stambach A, 2000, op. cit. (see reference 14).

37. Ibid.; and Bledsoe C, 1990, op. cit. (see reference 14).

38. Stambach A, 2000, op. cit. (see reference 14).

39. Silberschmidt M, 1992, op. cit. (see reference 14).

\section{RESUMEN}

Contexto: En el África subsahariana, donde las tasas de violencia contra la pareja son elevadas, es crucial conocer la frecuencia del abuso y los patrones de riesgo conexos para asegurar la salud y el desarrollo de la mujer. La violencia contra la pareja en Tanzania no ha sido evaluada a través de una encuesta con base en la población.

Métodos: Con base en una muestra de hogares de mujeres de 20-44 años residentes en el distrito urbano de Moshi, en el norte de Tanzania, se llevaron a cabo entrevistas personales en 2002-2003. Entre las 1.444 mujeres que indicaron que en ese momento tenían una pareja, se indagaron sobre su experiencia de la violencia doméstica durante el transcurso de la viday la ocurrida durante los últimos 12 meses. Se utilizaron análisis de regresión logística con múltiples variables para identifcar los factores relacionados con la violencia contra la pareja. Resultados: El 21\% de las mujeres indicaron que, durante los últimos 12 meses, habian sido objeto de la violencia doméstica (por ejemplo, habian sido amenazadas con abuso físico, sujetas a actos de abuso físico o forzadas por su pareja a mantener relaciones sexuales); el 26\% indicaron que habian sufrido esta violencia alguna vez, inclusive durante los últimos 12 meses. Las probabilidades de violencia aumentaban si la mujer había tenido problemas para concebir o si había dado a luz cinco o más veces (razones de momios de 1,9 y 2,4, respectivamente); si el cónyuge o pareja tenía otras parejas $(2,0)$ o si contribuía poco a los gastos del hogar para ella y sus hijos (3,3); y si tenía solamente educación primaria $(1,7)$.

Conclusiones: La desigualdad de género de las uniones sexuales está relacionada con la violencia contra la pareja. Las políticas y programas que tratan de que el hombre no culpe a la mujer por la infecundidad que sufre la pareja, que promue- ven las uniones monogámicas e incrementan el acceso de la mujer a la educación pueden reducir la violencia contra la pareja en los centros urbanos de Tanzania.

\section{RÉSUMÉ}

Contexte: En Afrique subsaharienne, où les taux de violence par un partenaire intime sont élevés, il est essentiel, pour assurer la santé et l'épanouissement des femmes, d'en connaître la prévalence et les tendances de risque. En Tanzanie, cette violence n'a été évaluée par aucune enquête en population générale.

Méthodes: Un échantillon de femmes de 20 à 44 ans prélevé parmi les ménages du district urbain de Moshi, en Tanzanie, a participé à des entrevues personnelles en 2002-2003. La prévalence totale de l'exposition à la violence par un partenaire intime et celle de l'exposition durant les 12 derniers mois ont été évaluées parmi 1.444 femmes ayant déclaré avoir un partenaire au moment de l'entrevue. Les facteurs associés à la violence intime ont été identifiés par régression logistique multivariée.

Résultats: Vingt et un pour cent des femmes ont déclaré avoir subi la violence d'un partenaire intime (menaces et actes de violence physique ou rapports sexuels forcés) durant les 12 mois précédant l'entrevue; $26 \%$ ont déclaré l'avoir subie à un moment ou à un autre, y compris durant les 12 derniers mois. La probabilité de la violence est apparue élevée quand la femme avait eu des difficultés à concevoir ou avait eu au moins cinq enfants (rapports de probabilités, 1,9 et 2,4, respectivement); quand son mari ou partenaire avait d'autres partenaires $(2,0)$ ou contribuait peu aux dépenses nécessaires à sa subsistance et à celle de ses enfants (3,3); et quand la femme n'était instruite, au plus, qu'au niveau primaire $(1,7)$.

Conclusions: L'inégalité sexuelle au sein des unions est associée à la violence par un partenaire intime. Les politiques et programmes luttant contre le blâme des femmes en cas de stérilité, encourageant les unions monogames et étendant l'accès des femmes à l'éducation pourraient réduire cette violence dans les milieux urbains de la Tanzanie.

\section{Acknowledgments}

This study was funded by grant RO1 HD 41202 from the United States National Institutes of Health/National Institute of Child Health and Human Development. Preliminary results were presented at the annual meeting of the Population Association of America, Philadelphia, PA, USA, Mar. 31-Apr. 2, 2005. The authors thank Said Aboud, Mlemba Abassy, Emillian Karugendo, Fred Matola and Marianne Massawe for their very valuable collaboration on data collection, and Saidi Kapiga for valuable advice and support from the outset of the project.

Author contact:1mcclosk@sp2.upenn.edu 